\title{
TRADUCEREA POEZIEI LUI EUGEN COȘERIU ÎN LIMBA GERMANĂ
}

\author{
Olesea GÎRLEA \\ Instituţia Publică Liceul Teoretic „Mircea Eliade”
}

\begin{abstract}
Rezumat. Indiscutabil poeziile lui Eugen Coșeriu au intrat în vizorul criticii din perspectiva impunerii unei revizuiri riguroase a operei. Traducerea poeziilor lui E. Coșeriu în toate limbile, inclusiv limba germană e un subiect generat de un concurs de la Biblioteca „B. P.-Hasdeu”, derulat în anul 2021. Lingvist cu renume mondial și cadru didactic internațional de excepție, Eugen Coșeriu a evitat să-și scrie opera poetică în limba germană. Demararea acestui concurs de traducere readuce în discuție opera poetică a lui E. Coșeriu din perspectiva traducerilor în diverse limbi, de diferite categorii de traducători de la elevi, până la traducători profesioniști.
\end{abstract}

Cuvinte cheie: traducere, poezie, accente stilistice, atitudine critică, spirit al vremii.

Abstract. Undoubtedly, Eugen Coșeriu's poems have come to the attention of critics from the perspective of imposing a rigorous revision of the work. The translation of E. Coșeriu's poems in all languages, including German, is a subject generated by a competition from the Library „B. P.-Hasdeu ”, held in 2021. A world-renowned linguist and an exceptional international teacher, Eugen Coșeriu avoided writing his poetic work in German. The start of this translation contest brings back into discussion the poetic work of E. Coșeriu from the perspective of translations into various languages, of different categories of translators from students to professional translators.

Keywords: translation, poetry, stylistic accents, critical attitude, spirit of the time.

A traduce, din limba română în limba germană, opera poetică a lingvistului de talie mondială Eugen Coșeriu este un mare privilegiu și o onoare. Provocarea a început în urma unui concurs de traducere organizat în primăvara anului 2021 de către Biblioteca Municipală „B. P. Hasdeu”. În cadrul acelui concurs s-a propus pentru traducere poemul Sângele nostru. Pentru care am selectat două variante reușite de traducere de către elevii claselor a VII-a ai Liceului Teoretic „Mircea Eliade" în care predau limba germană. E vorba despre Cristian Sochircă și Babin Evelina. Care s-au ales cu locul III pentru traducere și o menţiune. Pentru că nu au existat limite de vârstă, elevii au concurat alături de maturi, iar rezultatul obținut este meritul muncii asidue depuse de elevi. Traducerile prezentate în cadrul 
concursului vor figura într-o carte, care este în proces de pregătire, ceea ce constituie o performanță dublă pentru elevi.

Eugen Coșeriu își publică poeziile între anii 1939-1940 în diverse ziare și reviste Jurnal literar, Ziarul Moldova (Iași), Cuget moldovenesc, Viața Basarabiei. Din punct de vedere al evenimentelor istorice, acești ani sunt marcaţi de ocuparea sovietică a Basarabiei și de impunerea unui regim al dictaturii și terorii, la care nu putea fi indiferent tânărul optsprezece/nouăsprezece ani de atunci, Eugen Coșeriu; care-și făcea studiile la Iași și care a fost remarcat de către unul dintre profesorii săi, criticul literar George Călinescu.

Versurile sale tratează aspecte tematice diferite cum ar fi revolta faţă de teroarea istoriei, ironia sorții, tristețea, încercarea de autodefinire, perfecțiunea și efemeritatea dragostei, ironia zeflemitoare, nevoia de pace și liniște, împăcarea cu sine, mândria față de ,apartenența la un neam cu vocația jertfei” (Leanu, 2001, p. 131). Scrise la vârsta de 19 și respectiv 20 de ani, versurile conturează portretul unui poet în formare cu atitudine critică și spirit de observație, cu nerv și tact, cu multă căldură pentru descrierea lucrurilor dragi și neîndurare fără compromisuri față de părtașii și factorii principali de decizie ai manipulărilor, deportărilor și terorii.

În anul 2021 la editura Știința apare volumul Eugen Coșeriu: vocația universalității, consacrat sărbătoririi centenarului Eugen Coșeriu. Cele câteva poezii (11 la număr) scrise de către Eugen Coșeriu sunt analizate cu migală de către profesorul Nicolae Leahu, care remarcă faptul că poetul debutant a dat dovadă de ,o înzestrare lirică remarcabilă”, iar poeziile lui E. Coşeriu au intrat în vizorul criticii datorită impunerii unei revizuiri integrale a operei sale. Criticul literar Mihai Cimpoi precizează (în cadrul Conferinței internaționale „Filologia modernă: realizări și perspective în context european” cu genericul „Eugeniu Coşeriu: 100 ani de la naștere. Limbajul ca sumă de valori”, organizat de Institutul de Filologie Română „B. P.-Hasdeu”) faptul că opera poetică a lui E. Coșeriu „,nu este eclipsată de monumentala sa operă lingvistică”. Mihai Cimpoi vorbește despre persistența în proza și în poezia coșeriană a toposului înstrăinării, care este asociat izomorfic cu cel al predestinării, prilejuite de îndepărtarea de „vatra basarabeană”. Un alt moment surprins în creația poetică a lui E. Coșeriu de către M. Cimpoi este starea de neliniște și angoase, „situația catastrofală a pierderii identităţii”, ,absurditatea existențială a existenței”.

Putem constata astfel că dacă preocuparea pentru poezie ar fi persistat continuu, astăzi am fi putut vorbi cu certitudine despre Eugen Coșeriu ca despre un mare poet. Chiar și așa poeziile sale devin o mărturie a interesului pentru literatura universală și cea națională, a influențelor poetice consemnate de criticii literari George Călinescu, Adrian Dinu Rachieru, Nicolae Leahu, Alina Tofan, Mihai 
Cimpoi, Cornel Mihai Ionescu, care au stabilit asemănări și corespondențe cu lirica lui Lucian Blaga, Alexandru Macedonski, Ion Minulescu, Ion Barbu. Poeziile lui E. Coşeriu conţin diverse accente stilistice și tematice și se impun prin formule tradiționaliste, romantice, simboliste; ele sunt rod al reflecțiilor trăite și sunt determinate de necesitatea impunerii unei atitudini critice față de realitățile istorice nemiloase și spiritul vremii.

\section{Proverb}

Poate că-s adormit în somn letargic de veacuri,

Undeva departe s-au topit stelele;

Joacă acum, joacă în gându-mi ielele,

Ca uneori, când e noapte cu lună, pe lacuri.

Sunt trist şi rănit ca o carte cu filele rupte.

Fără să vreau m-au zăpezit amintirile:

Popi aud pe nas cum citesc psaltirile Oameni prin minte-mi trec cu fețele supte.

Iată merg nesimţit și fără vamă, Printre pomii care și-au risipit florile.

Să mai aștept, să vii, să-mi redai comorile?

Magice voci de cocor din adolescență mă cheamă?

Jurnalul literar, 24 decembrie 1939

\section{Sprichwort}

Vielleicht bin ich seit Jahrhundertenden im tiefen Traum verschlafen

Irgendwo weit weg sind die Sterne

zerschmolzen;

Jetzt spielen, spielen in meinem Gedanken die Elfen,

Wie die Male auf den Seen, wenn Vollmond ist.

Ich bin traurig und verletzt wie ein Buch mit gerissenen Blättern.

Die Erinnerungen haben mich mit Schnee bedeckt, ohne dass ich es wollte:

Ich höre wie Pfarrer den Psalter näselnd lesen Leute fallen mich im Gedanken mit eingefallenen Gesichte.

So gehe ich unbemerkt und abgabenfrei, Durch die Bäume, die ihre Blumen zerstreut haben. Darf ich noch warten, dass du kommst, ummeine Schätze zurückzugeben?

Rufen mich magische Kranichstimmen aus der Jugendzeit?

Jurnalul literar, 24 decembrie 1939

\section{Sângele nostru}

Din sângele nostru s-au hrănit atâtea popoare,

\section{Unser Blut}

Aus unserem Blut

haben sich so viele Völker ernährt 
Din sângele nostru

s-au născut

poeți şi cărturari ruși,

Mai ruși decât rușii

Din sângele nostru

s-au născut

voievozi, și regi maghiari,

hatmani de cazaci,

fruntași albanezi,

fruntaşi sârbi,

fruntași kirghizi.

Din sângele nostru s-au născut

cârmuitori,

eroi şi vlădici greci,

Mai greci decât grecii.

Dar să nu vă temeți,

Nu! Nu vă cerem să ni-1 dați înapoi -

Sângele pe care vi l-am dăruit,

la nord și la sud de Dunăre!

Vă rugăm numai să nu ni-1 cereți

şi pe cel

pe care îl mai avem.

Lăsaţi-ne și nouă

măcar câteva picături

ca să ne putem înfățişa cu ele,

ca noi înșine,

la judecata de apoi.
Aus unserem Blut

entstanden

russische Dichter und Gelehrte, russischer als die Russen

Aus unserem Blut

entstanden

Wojewode und ungarische Fürsten,

Feldherren von Kosaken,

albanische Anführer

serbische Anführer

kirgisische Anführer

Aus unseren Blut entstanden

griechische Hauptmänner,

Helden und Herrscher

griechischer als die Griechen.

Haben sie doch keine Angst,

Nein! Wir fordern euch nicht,

es zurückzugeben -

Das Blut, das wir euch geschenkt haben, im Norden und im Süden der Donau!

Wir bitten euch nur, es von uns nicht zu erfordern,

das Blut,

das wir noch haben.

Lassen sie uns doch wenigstens einige Trophen

damit wir als wir selbst mit diesen

beim letzten Gericht

auftreten können.

\section{Imn nocturn}

\section{Nachthymne}

Fată de vis, - fantomă te duci, Iluminată și rece te duci,

Mers alb arcuind printre cruci.

Fată de vis, - pe bolte treci,

Traummädchen, - du gehst als Gespenst, beleuchtet und kühl gehst du, wie ein weißer Gang gewölbt durch die Kreuze.

Traummädchen, - durch Himmelsgewölbe gehst du, 
$\mathrm{Cu}$ trupul amar de ierburi treci,

Pe sub zboruri de lilieci.

Fată de vis, - peste ape plutești, Blestem ori rugă plutești,

Fluturând tânguite povești. Fată de vis, - din goluri vii, Din stele ori din oceane vii,

$\mathrm{Cu}$ buzele arse de soare sălcii.

Fată de vis, - ciudat suspini.

De ce umblând prin păduri suspini,

Închinând la pini, rădăcini?

Ziarul Moldova (Iași), 1940

\section{Voia ta}

Ce mai putem vorbi, prietene acum -

Când nici porumbi, nici corbi nu ne trec prin suflet?

Gândul ni-i uitat, obosit de umblet...

Brațe ridici și-ndată se sting ca un fum.

E greu să ne creștem viața din călimări,

După ce am lăsat-o-n soare să se ofilească,

Și totuși mâinile, vorbele noastre de iască

Tot mai nădăjduiesc târzii mângâieri.

Rar de tot și grav ne sună bătăile-n poartă.

Dintr-odată toate ușile larg se deschid;

Neîndrăzneață privirea i se strecoară timid;

Deșert brăzdat de tăceri de apă moartă.

Cuget moldovenesc, 1940
Mit dem von Kräuter bitter gewordenen Leib gehst du,

Unter den Fledermausflug.

Traumädchen, - auf Wasser schwimmst du,

Als Verdammung oder Gebet

schwimmst du

wehklagende Märchen winkend.

Traummädchen, - aus Leere kommst du, Aus Sternen oder aus dem lebendigen

Ozeane,

Mit sonnengebräunten, brackigen Lippen.

Traummädchen, - du seufzt komisch.

Warum seufzt du durch die Wälder herumgehend,

Anbetend an Kiefern, an Wurzeln?

Ziarul Moldova (Iași), 1940

\section{Dein Wunsch/Dein Willen}

Mein Freund, worüber können wir jetzt noch sprechen -

Wenn uns weder die Tauben noch Raben durch die Seele gehen?

Unserer Gedanke ist vergessen, erschöpft vom Wandern...

Du hebst dieArme hoch und sie löschen sich wie ein Ruch aus.

Es ist schwierig, das Leben aus der

Tintenfass groß zu ziehen,

Nachdem wir es in die Sonne zu verwelken gelassen haben,

Und trotzdem unsere Hände und

Hoffen noch auf verspätete Zärtlichkeiten.

Zunderwörter

Sehr selten und bedrohlich klingeln Schläge an die Tür.

Sofort alle Türen öffnen sich breit;

Der unmutige Blick schleicht sich

schüchtern ein;

Eine Wüste, vom Schweigen des Todeswassers gefurcht.

Cuget moldovenesc, 1940 
Vine o corabie din nord,

Încet cu pânzele lăsate,

$\mathrm{Cu}$ fețele dure-ntunecate,

$\mathrm{Cu}$ marinari bolnavi pe bord.

Începe-un cânt în trist acord,

$\mathrm{Cu}$ dor de țări îndepărtate,

Vine o corabie din nord,

Încet, cu pânzele lăsate.

Ea poartă trupul unui lord

Nebun, sfârșit într-o cetate

Cu flamuri negre, sfâșiate,

Din neguros străfund de fiord

Vine o corabie din nord.

Jurnalul literar, 1939

\section{Puncte cardinale}

La nord de Cercul polar, rătăcesc moldovenii prin noapte, În căutare de sălașuri de iarnă.

Se poticnesc și cad în troiene.

Lupii miloşi din Carelia

le sfâşie pieptul cu colții:

nu-i lasă să moară de frig.

La est de lacul Aral, rătăcesc moldovenii prin arșița Stepei flămânde, în căutare de vreo oază cu izvoare. se poticnesc și cad în nisip. caii miloși din Kazahstan le sfarmă țeasta cu copita:

nu-i lasă să moară de sete.

La sud de munții Stanovoi, rătăcesc moldovenii
Ein Schiff kommt von Norden

Langsam, mit gestrichenen Segel,

Mit harten, verdunkelten Gesichte

Mit kranken Seemännern an Bord.

Ein Lied beginnt im traurigen Akkord, aus Sehnsucht nach fernen Ländern

Kommt ein Schiff von Norden

Langsam, mit gestrichenen Segel.

Es trägt den Leib eines Lords,

Der, verrückt, sein Ende in einer Festung

Mit schwarzen, zerrissenen Fahnen fand,

In der nebelhaften Tiefe des Fjords

Ein Schiff kommt von Norden.

Jurnalul literar, 1939

\section{Kardinalpunkte}

Im Norden von Polarkreis

Verirren sich die Moldauer durch die Nacht, Auf der Suche nach Wintersiedlungen,

Sie stolpern und fallen im Schneehaufen.

Die mitleidigen Wölfe aus Karelien

Zereisen ihnen die Brüste mit Zähnen:

Sie lassen die Moldauer nicht von Frost zu sterben.

Im Osten von der Aral See, Verirren sich die Moldauer

Durch der Hitze der hungrigen Steppe, Auf der Suche nach einer Oase mit Quellen. Sie stolpern und fallen im Sand.

Die mitleidigen Pferde aus Kazahstan

Zerbrechen ihnen den Hirnschädel

mit dem Huf:

Sie lassen die Moldauer nicht von Durst zu sterben.

Im Süden von Gebirgen Stanowoi verirren sich die Moldauer 
prin luncile Amurului,

în căutare de ciuperci

și rădăcini hrănitoare.

Se poticnesc și cad în hăţişuri.

Tigrii miloși e pe Amur

le frâng grumazul cu laba:

nu-i lasă să moară de foame.

La vest de Nistru

de la Mare la Hotin,

copii moldovenilor,

școlari și școlărițe,

cântă voioși în limba lor nouă:

„Mărite ție, Împărăție roșie,

mărite ție,

mărite și ție, mai ales ție,

țar de oțel,

stăpân înțelept,

tătuc iubitor de oameni,

părinte iubit de noroade.

Că de n-ați fi fost voi,

$\mathrm{N}$-ar fi ajuns moldovenii în Carelia,

nici în Kazahstan, nici pe Amur,

Și n-ar fi avut parte

de mila lupilor,

de mila cailor,

de mila tigrilor"

de la Mare la Hotin,

Din Hotin și pân' la mare.

\section{Mimoza}

Liniște. Pasărea Phoenix a trecut prin solitudini.

Moment mic. Moment bun. Șerpi de cer.

Arse câmpii au vibrat în latitudini: auf die Wiesen des Amurs,

auf der Suche nach Pilzen

und nahrhaften Würzeln.

Sie stolpern und fallen in Gestrüche.

Die mitleidigen Amurtiger

Brechen ihnen den Hals mit Tatzen:

Sie lassen die Moldauer nicht von Hunger

zu sterben.

Im Westen von Nistru,

vom Schwarzen Meer bis zum Hotin,

die Kinder von Moldauer,

Schüler und Schülerinnen,

singen froh in ihre neue Sprache:

Ehre sei dir, rotes Kaiserreich

Ehre sei dir,

Ehre sei dir, vor allem Ehre sei dir,

Zar aus Stahl,

Weiser Herr,

Vater, der Menschen liebt,

Und von Volker geliebter Vater.

Wenn ihr nicht gewesen wären,

Dann hätten die Moldauer weder in Karelien, noch in Kasachstan,

noch auf dem Amur gelandet, Und hätten sie

kein Mitleid von Wölfen

kein Mitleid von Pferde

kein Mitleid von Tiger

erlebt"

vom Schwarzen Meer bis zum Hotin,

Von Hotin bis zum Schwarzen Meer.

\section{Mimose}

Stille. Phoenix Vögel ist durch

Einsamkeit gegangen.

Einzigartiger Moment. Guter Moment.

Schlangen auf dem Himmel.

Gebrannte Felder haben

in Breitengraden vibriert: 
Pasărea tremură în izvoare și-n eter.

Filozoful blând murise topit în poene;

Cineva i-a fript ochii - ca un mag, ca un zeu;

Filozoful blând a albit în gene.

Liniștea, pasărea, azurul, zmeul ori eu?

1940, Viața Basarabiei

\section{Jandarmul român bătea}

- litanie moldavă -

E vremea rănilor ce dor,

dor în popor și dor și-n mine.

Jandarmul român bătea,

Rusul deporta,

Rusul tortura şi omora.

Jandarmul român din Oltenia

bătea în Basarabia,

Rusul deporta în Siberia.

Jandarmul român din Basarabia

bătea în Oltenia,

Rusul tortura şi omora unde vrea.

Jandarmul român bătea,

M-a bătut și pe mine unul,

și era de la noi din sat.

Rusul deporta.

A deportat-o și pe mama unul

și era de undeva de pe Don.

Rusul tortura şi omora.

L-a omorât și pe tata unul,

și era undeva din Urali.

Ce greu era cu Românii!

Ce bine era cu Rușii!

Jandarmul român bătea,

Rusul deporta,

Rusul tortura și omora.

E vremea rănilor ce dor.
Der Vogel zittert in Quellen und im Äther.

Der sanfte Philosoph ist mit der Lichtung verschmolzen gestorben;

Jemand hat seine Augen gebrant wie einem Magus, wie einem Abgott;

Die Augenwimpern des sanften Philosophen sind weiß geworden.

Die Stille, der Vogel, das Himmelblau, der Drache oder ich?

1940, Viața Basarabiei

\section{Der rumänische Gendarm prügelt}

- Moldauische Litanei -

Es ist Zeit für die Wunden, die schmerzen,

Sie tun weh in meinem Volk

und in mich selbst.

Der rumänische Gendarm prügelte,

Der Russe deportierte,

Der Russe folterte und tötete.

Der rumänische Gendarm aus Oltenia

Prügelte in Bessarabien,

Der Russe deportierte nach Sibirien

Der rumänische Gendarm aus Bessarabien

Prügelte in Oltenia,

Der Russe folterte und tötete, immer wo er wollte.

Der rumänische Gendarm prügelte,

Einer von ihnen hat mich auch geschlagen, und er war aus unserem Dorf.

Der Russe deportierte,

Einer von ihnen hat auch meine

Mutter deportiert

und es war irgendwo am Don.

Der Russe folterte und tötete.

Einer von ihnen hat hat auch

meinen Vater getötet,

und es war irgendwo im Ural.

Wie schwer war es mit den Rumänen!

Wie gut war es mit den Russen!

Der rumänische Gendarm prügelte,

Der Russe deportierte,

Der Russe folterte und tötete.

Es ist Zeit für die Wunden, die schmerzen. 


\section{Referințe bibliografice:}

1. ANUȚEI, Mihai. Dicționar român-german. București: Lucman, 2000.

2. ISBĂȘESCU, Mihai. Dicționar german-român. București: Teora, 2002.

3. Coord. BURLACU, Alexandru, TOFAN Alina, Scriitori de la „Viața Basarabiei”, Chișinău: Hyperion, 1990.

4. LEAHU, Nicolae. Eugen Coșeriu: poetul și prozatorul. În: Eugeniu Coșeriu: Vocația universalității. p. 128-136, Chișinău: Știința, 2021. 